\title{
CONCEPTS OF GREEN PORT OPERATIONS - ONE KIND OF SELF DIAGNOSIS METHOD TO THE PORT OF SANTOS - BRAZIL
}

\author{
Delmo Alves de Moura \\ Federal University of $A B C$, Brazil \\ E-mail: delmo.moura@ufabc.edu.br \\ Davi Goulart de Andrade \\ Federal University of $A B C$, Brazil \\ E-mail: davigoulartandrade@gmail.com \\ Submission: $15 / 09 / 2017$ \\ Revision: 06/03/2018 \\ Accept: 15/03/2018
}

\section{ABSTRACT}

This paper aims to evaluate the sustainable performance within the concept of Green Port in the logistics operations. Through literature review about green port implementation in different ports worldwide, as well as the studies of various technologies and methods that aim to make the port environment more sustainable, this study will go through different levels, from the shipping loading and unloading, passing through all sectors and actors related to the movement of cargo inside the port, which may on the sustainable performance of the environment, to the inland transportation. The study focus on the reduction of emissions of pollutant gases such as sulfur oxides (Sox), oxides of nitrogen (NOx), atmospheric particulate matter (PM) and Carbon dioxide ( $\mathrm{CO} 2)$. The work addresses the possible innovations in the logistics operations inherent in the transportation, storage, and handling of goods, involving the analysis, types, and operations of the resources used in the port management of the largest port in Brazil, Port of Santos.

Keywords: Green Port, Sustainability, Green Logistics, Port Operations, Port of Santos 
INDEPENDENT JOURNAL OF MANAGEMENT \& PRODUCTION (IJM\&P)

http://www.ijmp.jor.br

v. 9, n. 3, July - September 2018

ISSN: 2236-269X

DOI: 10.14807/ijmp.v9i3.733

\section{INTRODUCTION}

As the World is becoming more concerned with the harmful effects that pollution may cause to Earth, the need for greener activities has been getting more attention, in order to reduce those effects. The global warming is becoming a term cited more frequently, and it can be defined as the heating of the atmosphere, as it naturally occurs in vast of time, but it is not only due to natural causes. The problem is that the pollutants released by human activity speed up this process and may cause harm to living beings on Earth.

Around 3\% of the gross global emission comes from shipping activities, and this is an amount that cannot be disregarded since it has a significant impact on the environmental quality of the Earth (LI; LIU; JIANG, 2011). The logistics processes attempt to execute their activities in such a way that it saves both time and cost. Hence, integrating this concept with sustainability, the green logistics aims to achieve both economic and environmental satisfaction, which can lead to improved business competitiveness by reducing emissions and distribution cost due to the need for a new efficient logistics system (PARK; YEO, 2012).

Ports are places with high level of operations, where there are much cargo handling equipment and traffic. Therefore, the operations of those equipment, vehicles, trains and ships generate many pollutants, such as air pollution, which implies the emission of carbon dioxide (CO2), methane $(\mathrm{CH} 4)$, sulfur oxides (SOX), nitrogen oxides (NOX) and particulate matter as well, ports may have different impacts on the environment surrounding them, especially if it is close to urban areas.

Besides air pollution, problems like noise pollution, dredging, water contamination and the constant risk of releasing accidentally hazardous material are also present. Such problems, like those gathered with the need to lower utilization of energy levels, as well as the development of ecological protection and a healthy living nearby the terminals, implied the creation of a Green Port concept, where an environment could be built in order to improve the environmental efficiency, as well as economic aspects and social linkages with the surrounding community (DARBRA et al., 2005; YANG, 2017).

The use of liquefied natural gas (LNG) in port operations can contribute significantly to reduce emissions if compared to the ships' traditional engines that 
INDEPENDENT JOURNAL OF MANAGEMENT \& PRODUCTION (IJM\&P)

http://www.ijmp.jor.br

v. 9, n. 3, July - September 2018

ISSN: 2236-269X

DOI: 10.14807/ijmp.v9i3.733

use diesel (ACCIARO et al., 2014). LNG is the cleanest fossil fuel and has the potential to reduce the emission of the following gases: NOX - 92\%; CO2 - 23\%; SO2 - 100\% and Atmospheric Particulate Matter - 100\%.

The use of LNG as a fuel for water transport was tested on 35 vessels in Norway. In March 2013, the Port of Stockholm became one of the first ports in the world to offer LNG as a ship fuel. It was a passenger ship - a ferry (CLEANSHIP, 2013).

The association of the Baltic ports has developed an infrastructure for LNG to be the fuel for ships in some ports in the Baltic Sea region. That association has had the support of the main industrial organizations as ship-owners, the national organization of the ports and the ESPO - European Sea Ports Organization.

Long-term exposure to atmospheric particulate matter (PM) and Nitrogen oxides (NOx) has a significant effect on the health of employees working directly in port operations, as well as in the local population (TANG et al., 2017; PERIS-MORA et al., 2005; HARTMAN; CLOTT, 2012).

The increasing volumes of cargo have intensified the impacts on the marine environment. Due to those impacts, necessities of protecting the marine environment and creating a new eco-port concept have surged with the objective to reduce emission of greenhouse gases e pollutants, create a port environment where it can be possible to conserve the marine life, control the pollution and the energy consumption, as well as to keep the place an attractive environment. Also, this new concept of green environment improves the competitiveness of the ports and increase the trend to become environmentally-friendly, that is why many ports around the world are struggling to become greener ports (LIAO et al., 2016).

The community requested many ports in Europe to adopt greener activities based on different surveys applied by the European Sea Ports Organizations (ESPO)/Eco ports. Those changes in activities can be used in several operations, for example, port planning, cargo handling, and industrial activities are among the sectors where environmental issues can be present, and alternatives can be implemented. The implementation of greener alternatives in ports can be beneficial since it increases the potential of being more attractive to investors and partners, in particular with the support of the community (LAM; NOTTEBOOM, 2014). 
INDEPENDENT JOURNAL OF MANAGEMENT \& PRODUCTION (IJM\&P)

http://www.ijmp.jor.br

V. 9, n. 3, July - September 2018

ISSN: 2236-269X

DOI: 10.14807/ijmp.v9i3.733

This incentive of implementing greener alternatives in port activities in different countries, especially when those implementations bring good results, can inspire other countries just like Brazil, to adopt such alternatives, to collaborate not only with the local environment but also aiming to contribute significantly to the reduction of the global pollution.

This paper aims to bring an approach to the definition of Green Port at the Port of Santos, Located in Santos - São Paulo - Brazil. The main idea is to identify and analyze the green operations that are currently happening at the port, through pointing out sustainable logistics indicators to analyze the logistics activities in different terminals.

Also, the paper will focus what the port authority has been doing when it comes to environmental sustainability, as well as the private companies that operate at this port, through the application of specific questionnaires. A study regarding the viability of the electrification of cargo handling equipment $(\mathrm{CHE})$ in the logistics operations to analyze the reduction of emission through fossil fuels will also be on the topic.

The study of the viability of further green implementations based on the methods that modern ports with the title of Green Port is something that can bring many benefits to the city of Santos since it can help the local environment by reducing the emission of pollutants through clean and efficient operations at the port. This study also aims to enrich the literature by bringing an extensive analysis of the green operation in the Port of Santos, where there is a lack of knowledge related to the green logistics in that area.

\section{THEORETICAL BACKGROUND}

For many years, the problems regarding emissions of ships and port operations were not the main concern until events that had a very harmful impact on the environment, such as oils spills happened in the past years. Those events caused many negative effects on the environment and came up as something that needed attention. From this point, in the recent years, the creation of sustainability reports to certain environmental organizations, as well as, the need for an implementation of green logistics with a proactive focus, all within technical, operational and economic focus have surged (DAVARZANI et al., 2016). 
INDEPENDENT JOURNAL OF MANAGEMENT \& PRODUCTION (IJM\&P)

http://www.ijmp.jor.br

v. 9, n. 3, July - September 2018

ISSN: 2236-269X

DOI: 10.14807/ijmp.v9i3.733

There are many ports worldwide, and it is evident that the marine transportation plays an exceptional role in the global international trade, since around $80 \%$ of the volume of goods is carried out by ships between those ports. With the emergence of the need for greener activities from the recognition of protection of the marine environment and the fact that ports have a significant impact on the environment that they are situated, the term "Green Port" has emerged with relative importance (LIAO et al., 2016).

Different shipping companies have started to take initiatives to help with the environmental issues; those are called green shipping practices (GSP). Those practices comprehend the management of different activities, like waste reduction, resource conservation and practices such as counting the carbon footprint of all the routes ships go through and also the changing in the form of transportation such as the transfer of goods, by utilizing fewer road trucks and smaller vessels for the transport of goods between main ports and secondary ports (LAl et al., 2011).

For Pavlic et al. (2014), the energy consumption in ports is huge due to the different kinds of cargo handling equipment, such as rubber tired gantry (RTG) cranes, reach stackers, yard tractors, wheel loaders and forklifts. Stakeholders may be aware of that energy consumption because when you have energy and environmental management systems, this can lead to a better knowledge regarding the activities, and it allows them to better plan strategies.

Moreover, when it comes to the energy consumption in ports, one of the most difficult challenges is to empower workers, especially those on the shop floor operating different vehicles and machines to achieve a better level of consumption by being properly instructed. For the author, many ports in the world found themselves in need of improving their process continuously to achieve economic growth while reducing adverse impacts on the environment.

Such activities and strategies came up with the definition of the term Green Port: "It is defined as a product of the long-term strategy for the sustainable and climate friendly development of port's infrastructure." To achieve a status of Green Port, every actor, from the management to the shop floor must act responsibly.

The concept of green port for Maritz and Yeh (2014) is a port characterized by a favorable environment, ecological protection and reasonable utilization of 
INDEPENDENT JOURNAL OF MANAGEMENT \& PRODUCTION (IJM\&P)

http://www.ijmp.jor.br

v. 9, n. 3, July - September 2018

ISSN: 2236-269X

DOI: 10.14807/ijmp.v9i3.733

resources, low energy consumption and low levels of pollution. It has to generate a Green Value to bear social responsibility. In addition, the green port implementation must be straight linked with the port management; otherwise, the success cannot be achieved.

The electrification is an essential item for a Green port. Several terminals have electrified their RTGs, which has been renamed the E-RTG. Some examples are the Modern Terminal Limited (Hong Kong) and Lazaro Cardenas Terminal (Mexico). Those terminals collaborate with the environment, reducing the emission of greenhouse gases (LIRN et al., 2013; PATRÍCIO, 2014).

The Port of Aalborg (Denmark) announced that it achieved to be the first CO2 neutral port in Denmark, along with being among the few $\mathrm{CO} 2$ neutral ports in the world.

Pavlic et al. (2014) describe what the main features that need to be implemented or changed to achieve the implementation of the green port concept are. Those changes apply to different sectors, such as the need of replacing the fossil fuel engines of the operational equipment to engines that use renewable energy as a source, or even the conversion of the old engines into more sustainable ones, such as converting from diesel to LPG (Liquefied Petroleum Gas).

The author also let it clear that the changes are not only in operational issues, but there is a need for making changes also in the management and the planning practices of the port, such as the monitoring of energy and water consumption, and the indicators of environmental quality.

At the beginning of a green port implementation, the port management must evaluate all the operations undergoing, all the environmental practices and the energy data, also the decentralization of the responsibilities and the empowering of employees, especially on the shop floor to achieve a better environmental performance. All this information must lead the management to have a commitment and active support.

The use of power from the port, called Onshore Power Supply (OPS) reduces adverse effects on the environment, such as noise and air pollution, as they allow the auxiliary engines of the ships to be switched off. Ships have to keep their engines running when at berth in a port to supply onboard equipment with energy. 
INDEPENDENT JOURNAL OF MANAGEMENT \& PRODUCTION (IJM\&P)

http://www.ijmp.jor.br

V. 9, n. 3, July - September 2018

ISSN: 2236-269X

DOI: 10.14807/ijmp.v9i3.733

When ships are connected to a power supply from land or by barge (LNG), they can shut down their engines to reduce air polluting emissions at least while at berth.

The implementation of the OPS allows an opportunity not only to improve quality but also to lessen the emission of carbon dioxide (CO2), one of the main contributors to the greenhouse effect. The power for OPS must be produced using renewable energies (ROH et al., 2016; LIRN et al., 2013; CLEANSHIP, 2013; ACCIARO et al., 2014; SCIBERRAS, et al., 2017; WALKER, 2016).

The use of the OPS can be profitable for the regular waterway transport line when the vessel always lands in the same port and terminals. For ships carrying containers, which usually dock at different terminals, such ports must have several terminals with adequate infrastructure to connect the OPS system to ships (ACCIARO et al., 2014; SCIBERRAS, et al., 2017; WALKER, 2016; CLEANSHIP, 2013).

The creation of KPIs (Key performance indicator) is also highlighted by the author, since it is a tool that can be very useful to assess performance efficiency, and for monitoring the operational performance because they help to decentralize the environmental responsibilities when implementing the green port concept.

In addition to the KPIs, the author also tells about the implementation of the Energy Performance Index (EnPI), which consists of a ratio between the actual energy consumption and the benchmark energy consumption, whereas these last ones were extracted from historical data, such as the operator, vehicle, time of the day and the volume of activity. EnPI has a set value of 1.0, if this ratio is higher than 1.0, it indicates that there is a problem in the performance. Those indicators are essential during the process of learning and the adaptation because they are useful tools to analyze the performance to implement the concept of a green port successfully.

Bergqvist and Zandén (2012) show the importance of planning a port's inland logistics, which consists in the linkage of the transportation of cargo through different modal types, such as rail, barge, and trucks, to hinterland places that have economic contact with the port. Ports have become so important regarding global logistics that their decisions influence the global and local logistics service providers directly. 
INDEPENDENT JOURNAL OF MANAGEMENT \& PRODUCTION (IJM\&P)

http://www.ijmp.jor.br

v. 9, n. 3, July - September 2018

ISSN: 2236-269X

DOI: 10.14807/ijmp.v9i3.733

The author makes it clear that it is very important for the ports' management departments to plan the port activities with the inland logistics activities in other to get a better economic and environmental performance. This planning for many times ends up leading the port authorities to choose rail or barge transportation, instead of road transportation since they deliver less delay compared to the utilization of trucks, less environmental impact, fewer costs and a better throughput in the port.

The design of hinterland transportation systems together with an efficient inland logistics planning may lead to a better performance both in economic and environmental terms, which leads the port closer to a green port status. The utilization of less fossil fuel is a key factor to achieve a better environmental performance through providing a cleaner air.

That is what Chang and Wang (2012) bring through their analysis of the emissions from ships. Around 60000 annual cardiopulmonary and lung cancer occur due to PM (Particulate Matter) emission from ships. Their study analyzed the possibility of changing the type of fuel used in vessels that currently are residual fuel to a distillate one. However, what makes it difficult is the fact that the distillate fuel has a higher cost and companies around the world are not ready for this change yet.

What ports with a green port status have been doing to ease this problem is the adoption of a low-speed policy for vessel within a certain area close to the port, which has shown positive results in the reduction of the emissions of particulate matter.

Maritz and Yeh (2014) also list the ten green port guidelines for good practices to reach a successful implementation of the green port concept. These are: Recyclable Material Selection; Waste Management; Saving Water Resources; Reduction in Energy Consumption; Use of Mass Transportation; Internal Environment Quality Promotion; Waste Emission Reduction; Water Quality; Effective Use of Port Land and Management of the Environment.

In addition to the ten green port guidelines, the author, based on different researches could develop a framework with key factors in the green port establishment. The establishment of a green port is first to split into three distinct areas. These are the Environmental Quality, the Environmental Construction and the 
INDEPENDENT JOURNAL OF MANAGEMENT \& PRODUCTION (IJM\&P)

http://www.ijmp.jor.br

v. 9, n. 3, July - September 2018

ISSN: 2236-269X

DOI: 10.14807/ijmp.v9i3.733

Resource Management; from these three sectors, it is possible to see the key factors that collaborate to the implementation of the green port concept:

- Environmental Quality - Carbon dioxide, Water quality, Land use and Environmental management.

- Environmental Construction - Expansion of planting, Green building, Comprehensive E-service and Wireless network in port.

- Resource Management - Material Selection, Management of waste, Water resource, Energy use and Transportation.

Chiu et al. (2014) went over the analysis that Maritz and Yeh (2014) brought with the split of green port implementation measures. To make a study case by using a Fuzzy AHP (Analytical Hierarchy Process) which is a decision-making process based on multiple attributes. He brings several hierarchies with different goals related to the implementation of a green port.

When it comes to port area pollution, there are different types of pollution sources at a port, and some of the major sources are the Cargo Handling Equipment. The largest equipment between those is the RTG (Rubber Tyred Crane), which is considered to be one of the main sources of pollution at the port. RTGs are cranes known for their efficiency in handling a large number of containers.

Their mobility makes it possible to rearrange them to improve the operational efficiency. Those cranes are traditionally powered by a diesel generator set consisting of a diesel engine coupled with an alternator. They have a capacity of moving container weighing up to 50 tones at a rate of 20 container moves per hour.

The cranes powered by diesel have some disadvantages such as high mechanical maintenance costs, a high level of exhaust and noise pollution, and also a high level of fuel consumption. There are different types of technology applied to RTGs to improve their performance, those are: variable-speed generators, flywheel energy storage, hybrid RTGs with regenerative braking and electrified zero-emission cranes, the Electric Rubber Tyred Gantry (eRTG).

The disadvantages of diesel-powered RTGs are leading to their replacement by eRTGs. In the past eRTGs were difficult to deal with since the power cable array reduced their mobility and flexibility, but today those problems have been overcome. 
(VUJIČIĆ et al., 2013; YANG; CHANG, 2013). These are some advantages of the eRTGs:

Reduction of maintenance costs, up to $70 \%, 95 \%$ savings of diesel consumption, reduction of operational costs, up to $70 \%$ and from $60 \%$ up to $80 \%$ reduction in $\mathrm{CO} 2$ emissions.

It is possible to note that eRTGs offer many benefits, especially regarding sustainability compared with the traditional RTGs. When it comes to the implementation of a green port concept, the electrification of ports is an ultimate strategy to reduce the emissions in that area, and equipment such as the RTGs are easier to replace or improve since they are straightly managed by the port authority (KIM et al., 2012).

Until this point of the paper, it is possible to understand that implementing the concept of Green port is not an easy task. The port is made of many different components, as previously mentioned, many factors need to be changed, as well monitored. That is why indicators are used; they are extremely important for implementing an EMS (Environmental Management System) at a port. Since indicators are quantitative information that is offered in real time, through their analysis, it is possible to monitor the improvements being made towards an objective (PUIG et al., 2017).

Belfiore (2003) also adds that the use of indicators to address environmental issues have been widely used in ICM (Integrated Coastal Management) because they are very important to demonstrate progress and compare results involving regions and projects portfolios. Among the literature, there are some definitions of indicators that can be considered relevant for this study, to have a well-established concept of indicators.

For Pavlic et al. (2014) an indicator may be defined as a characteristic which, when measured repeatedly, demonstrates ecological trends, and a measure of current state or quality of an area. For Le et al. (2014) an indicator is a variable that describes the state of a system.

When facing such environmental problems, it is possible to note how ports around the world have been implementing different practices towards a greener port environment. These practices may differ among the ports, but it is possible to note 
INDEPENDENT JOURNAL OF MANAGEMENT \& PRODUCTION (IJM\&P)

http://www.ijmp.jor.br

v. 9, n. 3, July - September 2018

ISSN: 2236-269X

DOI: 10.14807/ijmp.v9i3.733

that all of them leads to the same objective that is to protect the environment in different scales, global and regional. However, every port needs a starting point to start the green port practices.

The port, at first, must have a relevant level of environmental knowledge before the practical implementations, that is why a method called SDM (Self Diagnosis Method) has been developed. Through this method, it is possible to evaluate the environmental management of the port in question through a strategic questionnaire designated to environmental managers (DARBRA et al., 2004; ROMERO et al., 2014). The SDM method has five objectives, these are:

- To regularly review the environmental management performance in the port;

- to allow periodic self-evaluation of environmental improvement in the port;

- to compare the port environmental performance against a European benchmark;

- to identify environmental priorities in the port;

- to move towards the implementation of an environmental management system.

The SDM method may help to define its different areas to be improved, to reach a first level of environmental. Once the port has an environmental structure, it is possible to use better the EPIs (Environmental Performance Indicators) which help to track the continuous its improvements through scientific evidence and quantifiable measures.

EPIs can be defined as "an information tool that summarizes data on complex environmental issues to show overall status and trends of those issues." They can monitor different factors that influence the port, such as physical, biological, chemical, social, environmental and economic systems.

Moreover, they are important when it comes to the implementation of a certification of an EMS (Environmental Management System) as well as the PERS (Port Environmental Review System), EMAS (Eco-Management and Audit Scheme) and the International Organization for Standardization, ISO 14001 (PUIG et al., 2014). These certifications are the highlights for a reaching a status of a green port. 
INDEPENDENT JOURNAL OF MANAGEMENT \& PRODUCTION (IJM\&P)

http://www.ijmp.jor.br

v. 9, n. 3, July - September 2018

ISSN: 2236-269X

DOI: 10.14807/ijmp.v9i3.733

The SDM is an important component to complete PERS, since it can highlight the most significant shortfalls in environmental management, which helps to set the environmental objectives. The Self-Diagnosis Method consists of two sections, the Port Profile and the Environmental Management and Procedures (DARBRA, 2004). It is made by nine different sections and 253 qualitative questions designed to be a user-friendly tool (PUIG, 2017).

After completing the SDM, the next step is the implementation of PERS, which is a management system specifically for ports and helps to define good practice standards, after this leads to the EMS guidelines. According to Maritz and Yeh (2014), EMS can be defined as a tool to manage environmental performance of an organization using a comprehensive, systematic and documented approach. It means it is the entrance to obtain an ISO 14001 or EMAS, which are the top of the environmental certifications (LE et al., 2014)

Seguí et al. (2016) let it clear about the importance of the implementation of green practices within the port operations. In order to reach a green status, it is important for a port to have knowledge of all their activities in different areas. That is why Seguí et al. (2016) created a questionnaire to monitor the activities of 27 different ports in Europe. It was based on different KPIs (key performance indicators) to determine what would be the best questions to ask the stakeholders to obtain an excellent result.

Among the sources to achieve effective KPIs the author used as his base, different methods used by the SDM, PEARL project, PPRISM project and PORTOPIA project, which was fundamental for the elaboration of the questionnaire. Moreover, it was possible to formulate five different criteria to develop an effective questionnaire. It was listed by the author, as the following points:

- Realistic: the proposed questions or indicators were accurately defined according to the characteristics and the real needs of the inland ports.

- Feasible: considering the current situation of inland ports, the answers of the proposed questionnaire were designed so that they involve few resources to report on them as well as a reasonable time. 
- Uncomplicated: linked to the last point, the questions proposed were easily formulated to make them understandable. Also, the questionnaire was launched in a user-friendly format.

- Qualitative: it has been observed that inland ports do not normally share figures of their performance with quantitative results. Therefore, it was considered to include qualitative questions in order to get better feedback from them.

- Added value: to persuade the inland ports to report the required information, it was necessary to show them the importance of the reporting culture to contribute in a positive benchmark that pushes ports into a better performance.

The questionnaire is made up of four different sections; these are environmental management, environmental monitoring, environmental priorities and green actions. Their study collaborated to enrich the PORTOPIA project's database. PORTOPIA (Port Observatory for Performance Indicator Analysis) is a project where European ports can manage their performance, based on KPIs that were previously selected (PORTOPIA, 2017).

Le et al., (2014) made a study about the preliminary steps of implementing green port practices in Vietnam. To make this study possible based his methods on the SDM to apply the questionnaires in the right way. The first step was to define who are the key stakeholders of the ports any group or individual who can affect or is affected by the achievement of the organization's objectives. Based on this he could define three different groups of stakeholders:

- Port's Environmental managers.

- Key actors of the port (employees, service staff and scientists).

- The neighborhood of the port.

Through his study, it was possible to develop three different questionnaires that could generate relevant data and questions that could be applied in interviews, to find the may environmental issues addressed by all the stakeholders, making it possible to compare the results among the five ports under study. 
Puig et al. (2017) bring an important tool to be used to develop a questionnaire for the beginning phases of the green port implementation. This tool is called Tool for the identification and implementation of Environmental Indicators in Ports (TEIP). The main reason to identify EPIs (Environmental Performance Indicators) is that they ensure that the daily activities of the ports are sustainably developed. The EPIs can not only be beneficial to the port authorities but to other stakeholders as well, since they are quantifiable measures, customers, shipping companies and also the community may take advantage of them.

There are three environmental standards mainly used at ports; these are: the International Organisation for Standardisation (ISO) 14001, the Eco Management and Audit Scheme (EMAS) Regulation and the Port Environmental Review System (PERS).

ISO 14001 do not provide any specific indicator to implement, but it gives examples that can be considered. However, both EMAS and PERS provide core EPIs to be used. PERS is the only protocol specific for ports. Puig et al. (2017) noticed that it was important to have a standard methodology that can provide specific results to any port since each port is different and need EPIs to ensure an environmental protection and sustainable development.

Through the TEIP tool, it is possible to obtain the most appropriate indicators to use in a particular port. That can be obtained from a user-friendly online tool for any port, inland port or seaports. The advantages of the TEIP are not only the acquisition of the right indicators, but it can also provide information about the port to exchange knowledge between different ports.

The basis of the EMS implementation has its origins back in 1998 with the ECOPORT project Towards A Sustainable Transport Network. The establishment of EMS had as its objective to create basic conditions to develop a sustainable management in European ports. The ISO 14001 was the first standard to open doors for the EMS implementation, and nowadays in Europe, it is a prerequisite in the certification process to obtain and EMAS, which is one of the major standards (PERIS-MORA et al., 2005).

Peris et al. (2005) still highlight the complexity of the variables at a port, and how difficult it can be to understand all of them in a complex ecosystem. As 
INDEPENDENT JOURNAL OF MANAGEMENT \& PRODUCTION (IJM\&P)

http://www.ijmp.jor.br

v. 9, n. 3, July - September 2018

ISSN: 2236-269X

DOI: 10.14807/ijmp.v9i3.733

mentioned by (BICHOU; GRAY, 2005) Seaports are complex, and dynamic entities, and Peris-Mora et al. (2005) add that it is barely possible to an individual try to completely understand it. For this reason, it was important to replace such variable by indicators in a limited number that could simplify the analysis.

Peris-Mora et al., (2005) also bring a list made of topics that indicate the general characteristics of port indicators. Following there are some of the most important topics:

- Representativeness: The indicators should represent environmental behavior accurately.

- Purpose: When indicators are evaluating an activity, they need to focus on goals that need to be accomplished.

- Usefulness: The indicators need to be useful to the activity.

- Comparability: The indicators should provide information to be compared to different ports.

- Sensitivity: The indicators should respond quickly, adaptable and appropriately to environmental changes.

- Clarity: The indicators should be concise, accurate, simple and easy to interpret.

- Reliability: The indicators should be reliable in obtaining and developing the data.

- Continuity: Data should often be collected to compare results.

- Scientific verification: The indicator should be preferably quantitative. If this were not possible, it should be hierarchically categorized.

It is possible to note that according to these last authors, the use of indicators is extremely important, not only to secure the environment that the port is situated, but they also collaborate to the economic growth of the port. Many certifications used by green ports, such as ISO 14001, EMAS and PERS use indicators during the implementation phase because they are mandatory to monitor the port sectors and obtain relevant data. 
INDEPENDENT JOURNAL OF MANAGEMENT \& PRODUCTION (IJM\&P)

http://www.ijmp.jor.br

v. 9, n. 3, July - September 2018

ISSN: 2236-269X

DOI: 10.14807/ijmp.v9i3.733

A problem we can notice is that, as mentioned by Puig et al., (2014), each port is unique. And through the observation of different ports and their activities, some may present ease for the implementation of an environmental certification, and some may not. In the case of Brazil, there is a lack of studies about this kind of implementation, if we compare to the studies about European ports.

However, Ross and Neto (2016) conducted a study regarding the environmental performance of some Brazilian ports. They could obtain some significant information from their study. In the 1990s a reformulation of the ports in Brazil was conducted. However, an environmental policy was not considered during this process, what contributed negatively to the growth of the environmental regulations in the country. Also, until 2013 only around $62 \%$ of the ports in Brazil had an environmental operating license, and unfortunately the Port of Santos was not among them.

Ross and Neto (2016) also noticed that there are two different environmental indicators systems in Brazil implemented by two different state agencies. Those are the PNLP (National Port Logistics Plan) developed by the SEP (National Secretary of Ports) and the IDA (Environmental Performance Index), developed by the ANTAQ (National Water Transport Agency).

The PNLP focus on the performance of the port as a whole, while the IDA has as its purpose to provide data on environmental management (PNLP, 2015; ANTAQ, 2017). However, both present operational indicators related to logistics, which can be integrated with new suggestions of sustainable indicators in the logistics operations at the port, as shown in Table 1:

Table 1: Agency and Indicator

\begin{tabular}{|c|l|}
\hline AGENCY & \multicolumn{1}{|c|}{ INDICATOR } \\
\hline ANTAQ & Removal of waste from vessels \\
\hline ANTAQ & Operations of containers containing dangerous products \\
\hline SEP & Port installations with adequate waiting time \\
\hline SEP & Modal distribution at the access to the ports \\
\hline SEP & Port with adequate level of roadway service \\
\hline SEP & Use of the railway capacity of the port accesses \\
\hline SEP & Growth percentage of cabotage (short sea shipping) movement \\
\hline SEP & Use of optimization systems of roadway flows \\
\hline
\end{tabular}


INDEPENDENT JOURNAL OF MANAGEMENT \& PRODUCTION (IJM\&P)

http://www.ijmp.jor.br

v. 9, n. 3, July - September 2018

ISSN: 2236-269X

DOI: 10.14807/ijmp.v9i3.733

The transportation of goods to different countries in the World, as a task of economic development, is an activity that has been largely used by the human kind since the years of 1700 BC (LUN et al., 2016). Many countries have been recently implementing their green activities related to port activities, especially in countries with major ports and enough infrastructures to invest on it.

Such as the Port of Tacoma in the United States that has been actively invested in environmental protection by extending its definition of an environment which includes everything in their port contexts such as a history of the place, culture, people, and business. Japan has also been highlighted, especially due to its port environment policies, where they went beyond the measure to make ports just sustainable places with low impact on the environment, but they also focused on making their ports places that are enjoyable and pleasant for people (PARK; YEO, 2012).

It is important to have a wide view of what is happening nowadays in the world, regarding the different implementations of the concept of green port, because through the literature review, as Allatar et al. (2006) said, each port is unique in its sense. By studying different cases, it is possible to have different perspectives, and by having different perspectives, it will be possible to have a greater knowledge which will make it better when it comes to making a case study, such as the Port of Santos, which is the goal of this paper.

Acciaro et al. (2014) give us a perspective on the importance of the energy management in ports to get better energy efficiency. He mentions that many ports are situated in places that are favorable for the implementation of renewable sources in their different forms. Example of ports that take advantage of power generation from wind-powered generation is the Port of Rotterdam in Netherlands and the Port of Kitakyushu in Japan, ports that use of wave power such as Port of Kembla in Australia and the Port of Mutriku in the Basque Country.

Also, ports that take advantage of tide differentials, Port of Digby in Nova Scotia, also ports that use geothermal energy such as the Port of Hamburg in Germany, and also ports that make the utilization of solar energy especially to the utilization in the administrative buildings, such as the Port of San Diego in the United States and the Port of Tokyo in Japan. 
Different countries in the world implement their green port concepts in many ways. That is what Lam and Notteboom (2014) bring with an example through their study comparing three major ports in the world; these are: Port of Antwerp in Belgium, Port of Rotterdam in Netherlands, Port of Shanghai in China and Port of Singapore in Singapore.

Every port applies the green port concept through different ways, but these four ports apply practices that are equal or similar, and one example of practice adopted by these ports is the reward and punishment scheme, especially related to the need to get a better Low Sulfur Fuel Oil (LSFO).

Ships with an emission level above allowed may suffer the application of penalties, while ships with a good standard of emission may receive discounts at the port. One of the most known schemes of rewarding ships that are being constantly implemented by several ports is the Environmental Ship Index (ESI). It consists of a calculation method to measure ship's overall performance, and based on the results discounts may be applied, for example, the Port of Antwerp offers a three-year discount on tonnages for companies that are investing in ESI.

Also, when implementing the green port concept, the author highlights that having a carbon footprint is a good start, and all the four ports bring their carbon footprint. The Port of Rotterdam has an outstanding program that captures the carbon dioxide (CO2) and stores it below the North Sea. This port is also known as the forefront port on the fight against the climate change. Together with the Port of Rotterdam, the Port of Antwerp also aims to reach an out-standing green status.

Both ports prioritize the modal split of hinterland transport with barge transport and rail transport instead of the road transport, in this term, they go ahead to the Port of Shanghai and the Port of Singapore. Therefore those tendencies make it clear that Europe had started to implement the green port concept earlier than Asia. Nevertheless, the four ports have focused on the same activities, prioritizing at first the ship traffic, followed by the cargo handling and storage, port expansion and port industrial activities.

The Port of Long Beach located in the United States is a model of green activities for several countries in the World. In 2005, this port formulated the first green policy, which consisted in initiatives that could positively contribute to the 
INDEPENDENT JOURNAL OF MANAGEMENT \& PRODUCTION (IJM\&P)

http://www.ijmp.jor.br

v. 9, n. 3, July - September 2018

ISSN: 2236-269X

DOI: 10.14807/ijmp.v9i3.733

environment (MARITZ and YEH, 2014). Different initiatives are applied to this port, and among them, it is possible to mention 3 of them, these are:

- The utilization of low-sulfur fuel in the main engines, as well as the incentive to the use of Liquefied Natural Gas (LNG).

- The Green Flag Program. The ships arriving in Long Beach were encouraged to reduce their speed when coming closer to the port, to reduce air pollution. If the ship keeps that practice for 12 months, it gets better dock charges and also the Long Beach Clean Port flag.

- The Clean Truck Program. This program consists in the prohibition of trucks manufactured before 1989. This program was implemented in 2008, and by 2012 the pollution levels were successfully reduced.

\section{RESEARCH METHODOLOGY}

The methodology used in this work was the bibliographic review on the subject and semi-structured interviews in the Port of Santos. The bibliographic review is a stage that brings knowledge subsidies and provides scientific support for the research. This study was based on papers and scientific material on the green port theme. Base on the existing literature, semi-structured interviews were conducted with port managers. Open-ended questions were asked at the end of the semi-structured interview to obtain further insights into the sustainable development of the Port of Santos The theoretical reference was supported basically by documentary and international journals.

Fieldwork was also used in this study since data were collected from people who contributed to the understanding of the problem and the application of sustainable operations in the Port of Santos. Therefore, in general, we used the exploratory research involving a bibliographical review, interview with people with practical experiences with the subject and analysis of examples that contribute to the understanding of the problem.

\section{ENVIRONMENTAL MANAGEMENT OF THE PORT OF SANTOS}

In 2016, the Port of Santos moved 2,358,220 containers out of 5,652,587 units, corresponding to $41.72 \%$ of the national movement. The port of Santos is of enormous importance for Brazilian import and export (GALVÃO, et al., 2016). All 
types of cargo, solid bulk and liquid, are transported through it. According to the World Shipping Council, the Port of Santos appears in the 39th position in the 2015 Top Fifties World Container Ports.

Some of the products transported are sugar, fertilizer, coal, sulfur, soybean meal, corn, iron ore, soybeans, gasoline, caustic soda, citrus juices, alcohol, and salt.

CODESP has been seeking to implement an Environmental Management System in its administrative units as a strategic decision. This system deals with the Environmental Audit in Organized Ports, as well as, to obtain the international certification ISO 14001 . The implantation of this system already is in progress. One of the most important steps in this process is the establishment of CODESP's Environmental Policy. This policy is CODESP's reference for the sustainable development of its activities. Due to its importance, it may be widely disseminated to all employees and outsourced personnel of the Company.

CODESP aims to:

- Fully comply with current environmental legislation and the standards defined by CODESP;

- Efficiency in the provision of port services, having as principle the conservation and environmental control;

- Prevent pollution in all its forms;

- Preserving the historical and cultural heritage of the region;

- Stimulating technological innovation in the search for opportunities for business growth and continuous improvement of the Environmental Management System; and

- Promote the constant training and qualification of its collaborators.

Even operating 24 hours a day, the Port of Santos is the only one in Brazil to have generation autonomy with its hydroelectric power plant. For 100 years, the Itatinga Plant, located in Bertioga, supplies energy to port and is now $80 \%$ of its demand. The Port of Santos also has an effluent treatment plant in Macuco, serving the right bank and a water treatment plant located in Saboó, which also supplies Barnabé Island. 
INDEPENDENT JOURNAL OF MANAGEMENT \& PRODUCTION (IJM\&P)

http://www.ijmp.jor.br

v. 9, n. 3, July - September 2018

ISSN: 2236-269X

DOI: 10.14807/ijmp.v9i3.733

The supply of energy for own consumption and the various lessees served by the system, is primarily from the Itatinga hydroelectric plant, with a capacity of 15 MW. The Alemoa Liquid Bulk Terminal is powered by CPFL - Companhia Paulista de Força e Luz (an energy supply company in the state of São Paulo).

Towers or poles of 10,15 and 20 meters in height are responsible for the external lighting. There are reflectors of $400 \mathrm{~W}$ sodium vapor lamps, with a built-in internal reactor or an external reactor, or on poles installed on the flaps of the warehouses with reflectors of 2 sodium vapor lamps, controlled by counters or photoelectric relays.

The solid waste management plan of the Port of Santos is the guiding instrument and mandatory compliance for all actors of the Organized Port. It consists of the adequate management of solid waste produced in all activities carried out in the Organized Port of Santos. The Environmental Management, along with the Occupational Health and Safety Management is the management and observational units of this Plan within the Organized Port of Santos.

The Environmental Policy of the Port of Santos is the protocol of intentions to be observed for the creation of the Environmental Management Systems of the Organized Port of Santos. The Environmental Policies of each lessee must be consonant with the Environmental Policy of the Port of Santos. Likewise, the Environmental Management Systems of each lessee must foresee the synergy between them and with the Environmental Management System of the Port Administration.

\section{CONCLUSION}

The Secretary of Ports (SEP), which is a Federal agency which has Ministry power, needs to implement a public policy with methodological accuracy to monitor port operations exhaustively and to allow public and private companies to invest in technology and innovation, aiming international certification of Green Port.

The Port of Santos studies the possibility of having a bulk terminal for solids operating sustainably, reducing the traffic of trucks and using the railroad to carry out the operations. The goal is to reduce by more than 600 a day traveling through that region and thereby reduce the emission of polluting gases and particulate matter into the atmosphere. 
INDEPENDENT JOURNAL OF MANAGEMENT \& PRODUCTION (IJM\&P)

http://www.ijmp.jor.br

v. 9, n. 3, July - September 2018

ISSN: 2236-269X

DOI: 10.14807/ijmp.v9i3.733

The Port of Santos environmental priorities must be air quality, energy consumption, noise, relationship with the local community, garbage-port waste, ship waste, port development-land related, water quality, dust, and dredging operations. It is necessary to be proactive in protecting the environment by providing guidance and preparing recommendations on environmental management (green guide), developing and promoting tools and methodologies for port environmental management and identified environmental indicators to monitor trends in environmental performance.

\section{Acknowledgements:}

Research supported by grant 2015/00277-8 São Paulo Research Foundation (FAPESP); Funding received from Federal University of $A B C$

\section{REFERENCES}

ACCIARO, M.; GHIARA, H.; CUSANO, M. (2014) Energy management in sea ports: A new role for port authorities. Energy Policy, v. 71, p. 4-12.

ALLATAR, M.; KARKARE, B.; RAJHANS, N. (2006) Simulation of Container Queues for Port Investment Decisions. The Sixth International Symposium on Operations Research and Its Aplications, p.155-167.

ANTAQ (2017) Retrieved from Agencia Nacional de Transportes Aquaviários: http://web.antaq.gov.br/Portal/MeioAmbiente_IDA.asp

BELFIORE, S. (2003) The growth of integrated coastal management and the role of indicators in integrated coastal management: introduction to the special issue.

Ocean \& Coastal Management, v. 46, p. 225-234.

BERGQVIST, R.; ZANDÉN, N. (2012) Green port dues - The case of hinterland transport. Research in Transportation Business \& Management, v. 5, p. 85-91.

BICHOU, K.; GRAY, R. (2005) A critical review of conventional terminology for classifying seaports. Transportation Research Part A, v. 39, p. 75-92.

CHANG, C.; WANG, C. (2012) Evaluating the effects of green port policy: Case study of Kaohsiung harbor in Taiwan. Transportation Research D, v. 17, p. 185189.

CHIU, R.-H.; LIN, L.-H.; TING, S.-C. (2014) Evaluation of Green Port Factors and Performance: A Fuzzy AHP Analysis. Mathematical Problems in Engineering, Article ID 802976.

CLEANSHIP, Clean Baltic Sea Shiping Report (2013). http://www.clean-baltic-seashiping.com/uploads/files/CLEANSHIP_final_report_for_download.pdf. Accessed 03/02/17.

DARBRA, R.; RONZA, A.; CASAL, J.; STAJONOVIC, T.; WOOLDRIDGE, C. (2004) The Self Diagnosis Method: A new methodology to assess environmental management in sea ports. Marine Pollution Bulletin, v. 48, p. 420-428. 
INDEPENDENT JOURNAL OF MANAGEMENT \& PRODUCTION (IJM\&P)

http://www.ijmp.jor.br

v. 9, n. 3, July - September 2018

ISSN: 2236-269X

DOI: 10.14807/ijmp.v9i3.733

DARBRA, R.; RONZA, A.; STAJONOVIC, T.; WOOLDRIDGE, C.; CASAL, J. (2005) A procedure for identifying significant environmental aspects in sea ports. Marine Pollution Bulletin, v. 50, p. 866-874.

DAVARZANI, H.; FAHIMNIA, B.; BELL, M.; SARKIS, J. (2016) Greening ports and maritime logistics: A review. Transportation Research Part D, v. 48, p. 473-487.

GALVÃO, C. B.; WANG, G. W. Y.; MILESKI, J. (2016) Public-Private Interests and Conflicts in Ports: A Content Analysis Aproach. The Asian Journal of Shiping and Logistics, v. 32, n. 1, p. 13-22.

HARTMAN, B. C.; CLOTT, C. B. (2012) An economic model for sustainable harbor trucking. Transportation Research Part D, v. 17, p. 354-360.

KIM, J.; RAHIMI, M.; NEWELL, J. (2012) Life-Cycle Emissions from Port Electrification: A Case Study of Cargo Handling Tractors at the Port of Los Angeles. International Journal of Sustainable Transportation, p. 321-337.

LAI, K.-H.; LUN, V.; WONG, C.; CHENG, T. (2011) Green shipping practices in the shipping industry: Conceptualization, adoption, and implications. Resources, Conservation and Recycling, v. 55, p. 631-638.

LAM, J.; NOTTEBOOM, T. (2014) The Greening of Ports: A Comparison of Port Management Tools Used by Leading Ports in Asia and Europe. Transport Reviews, v. 34, n. 2, p. 169-189.

LE, X.-Q.; VU, V.-H.; HENS, L.; HEUR, B. (2014) Stakeholder perceptions and involvement in the implementation of EMS in ports in Vietnam and Cambodia. Journal of Cleaner Production, v. 64, p. 173-193.

LI, J.; LIU, X.; JIANG, B. (2011) An Exploratory Study on Low-Carbon Ports Development Strategy in China. The Asian Journal of Shiping and Logistics, $v$. 27, n. 1, p. 91-111.

LIAO, M.-S.; DING, J.-F.; LIANG, G.-S.; LEE, K.-L. (2016) Key Criteria for Evaluating the Green Performance of Ports. Journal of Testing and Evaluation, v. 44, n. 4, p. 1791-1801.

LIRN, T-C.; WU, Y-C. J.; CHEN, Y. J. (2013) Green performance criteria for sustainable ports in Asia. International Journal of Physical Distribution \& Logistics Management, v. 43 n. 5/6, p. 427-451.

LUN, V.; LAI, K.-h.; WONG, C.; CHENG, T. (2016) Green Ship Management:

Shiping and Transport Logistics. Chapter 5. Springer International Publishing Switzerland. First Edition.

MARITZ, A.; YEH, S.-P. (2014) Innovation and Success Factors in the Construction of Green Ports. Journal of Environmental Protection and Ecology, v. 15, n. 3A, p.1255-1263.

PARK, J.-Y.; YEO, G.-T. (2012) An Evaluation of Greenness of major Korean ports: A Fuzzy Set Aproach. The Asian Journal of Shiping and Logistics, v. 28, n. 1, p. 67-82.

PATRÍCIO, M. (2014) Diagnóstico e proposta de modelo de avaliação operacional para automação em terminais de contêineres no Brasil. Doctoral Thesis. Naval and Oceanic Engineering. University of São Paulo, Brazil. 
INDEPENDENT JOURNAL OF MANAGEMENT \& PRODUCTION (IJM\&P)

http://www.ijmp.jor.br

v. 9, n. 3, July - September 2018

ISSN: 2236-269X

DOI: 10.14807/ijmp.v9i3.733

PAVLIC, B.; CEPAK, F.; SUCIC, B.; PECKAJ, M.; KANDUS, B. (2014) Sustainable Port Infrastructure, Practical Implementation of the Green Port Concept. Thermal Science, v. 18, n. 3, p. 935-948.

PERIS-MORA, E.; OREJAS, J.; SUBIRATS, A.; IBÁNEZ, S.; ALVAREZ, P. (2005) Development of a system of indicators for sustainable port management. Marine Pollution Bulletin, p. 1649-1660.

PNLP (2015). Executive Summary - Plano Nacional de Logística Portuária.

PORTOPIA. (2017). Retrieved from PORTOPIA: http://www. portopia.eu/ Accessed 09/09/17.

PUIG, M.; PLA, A.; SEGUÍ, X.; DARBRA, R. (2017) Tool for the identification and implementation of Environmental Indicators in Ports. Ocean \& Coastal

Management, v. 140, p. 34-45.

PUIG, M.; WOOLDRIDGE, C.; DARBRA, R. M. (2014) Identification and selection of Environmental Performance Indicators for sustainable port development. Marine Pollution Bulletin, v. 81, p. 124-130.

ROH, S.; THAI, V. V.; WONG, Y. D. (2016) Towards sustainable Asian port development: challenges and oportunities for Vietnamese ports. The Asian Journal of Shiping and Logistics, v. 32, n. 2, p. 107-118.

ROMERO, A.; ASMUS, M.; MILANELLI, J.; BURUAEM, L.; ABESSA, D. (2014) Selfdiagnosis method as an assessment tool for environmental management of Brazilian ports. Journal of Integrated Coastal Zone Management, v. 14, p. 637-644.

ROOS, E.; NETO, F. (2016) Tools for evaluating environmental performance at Brazilian public ports: Analysis and Proposal. Marine Pollution Bulletin, v. 115, p. 211-216.

SCIBERRAS, E. A.; ZAHAWI, B.; ATKINSON, D. J. (2017) Reducing shipboard emissions - assessment of the role of electrical technologies. Transportation Research Part D, v. 51, p. 227-239.

SEGUÍ, X.; PUIG, M.; QUINTIERI, E.; WOOLDRIDGE, C.; DARBRA, R. (2016) New environmental performance baseline for inland ports: A benchmark for the European inland port sector. Environmental Science \& Policy, v. 58, p. 29-40.

TANG, J.; MCNABOLA, A.; MISSTEAR, B.; CAULFIELD, B.; (2017) An evaluation of the impact of the Dublin Port Tunnel and HGV management strategy on air pollution emissions. Transportation Research Part D, v. 52, p. 1-14.

VUJIČIĆ, A.; ZRNIĆ, N.; JERMAN, B. (2013) Ports Sustainability: A life cycle assessment of Zero Emission Cargo Handling Equipment. Journal of Mechanical Engineering, v. 59, p. 547-555.

WALKER, T. R. (2016) Green Marine: An environmental program to establish sustainability in marine transportation. Marine Pollution Bulletin, v. 105, p. 199207.

YANG, Y.-C. (2017) Operating strategies of CO2 reduction for a container terminal based on carbon footprint perspective. Journal of Cleaner Production, v. 141, p. 472-480. 
ISSN: 2236-269X

DOI: 10.14807/ijmp.v9i3.733

YANG, Y.-C.; CHANG, W.-M. (2013) Impacts of electric rubber-tired gantries on green port performance. Research in Transportation Business \& Management, v. 8, p. 67-76. 